\title{
Land Use and Land Cover Change in a Community-Managed Forest in South-Eastern Senegal Under a Formal Forest Management Regime
}

\author{
Laurice Codou Faye ${ }^{1}$, Hyacinthe Sambou ${ }^{2}$, Boateng Kyereh ${ }^{3}$, Bienvenu Sambou ${ }^{2}$ \\ ${ }^{1}$ Department of Civil Engineering, College of Engineering, Kwame Nkrumah University of Science and Technology, Kumasi, Ghana \\ ${ }^{2}$ Institute of Environmental Sciences, Cheikh Anta Diop University of Dakar, Dakar, Senegal \\ ${ }^{3}$ Department of Silviculture and Forest Management, Faculty of Renewable Natural Resources, Kwame Nkrumah University of Science \& \\ Technology, Kumasi, Ghana
}

Email address:

fayelaurice@gmail.com (L. C. Faye)

\section{To cite this article:}

Laurice Codou Faye, Hyacinthe Sambou, Boateng Kyereh, Bienvenu Sambou. Land Use and Land Cover Change in a Community-Managed Forest in South-Eastern Senegal Under a Formal Forest Management Regime. American Journal of Environmental Protection.

Vol. 5, No. 1, 2016, pp. 1-10. doi: 10.11648/j.ajep.20160501.11

\begin{abstract}
While most studies of community forests in Senegal address issues in institutional and political arrangements for managing forests, this study was carried out to find out how these political and institutional changes embodied in the new approach to forest management impact on land use and land cover change in the country. Using the Missirah Forest in southeastern Senegal, as a case study, the objective was to quantify the land use and land cover changes that have happened over a twenty four- year period, from 1990 to 2014 using remote sensing. Six land use and land cover types were identified and mapped, namely, gallery forest, tree savanna, shrub savanna, degraded shrub savanna, croplands and settlements. The area of croplands and settlements expanded between 1990 and 2014. The conversion from natural vegetation to croplands (14.45\%) was higher than the conversion from cropland to natural vegetation (3\%). Between 1990 and 2003, the expansion in croplands was higher than between 1990 and 2003 but the reverse was the case for settlements. Regarding vegetation types, they decreased in cover between the two periods with the exception of shrub savanna that experienced an increase of $1.46 \%$ from 1990 to 2003 . Transition to less wooded vegetation (31.58\%) was higher than transition to more wooded vegetation (13.91\%). This study shows that deforestation and forest degradation are still in progress despite the implementation of a management plan for a full rotation.
\end{abstract}

Keywords: Land Cover Changes, Vegetation Transition, Community-Forest Management, Senegal

\section{Introduction}

In sub-Saharan Africa, land use and land cover change trends are extremely fast and the direction and rate of change are unstable [1]. Land use and land cover changes are often related to both natural and anthropogenic causes. But the most important driver of land cover and land use change is the intensive use of natural resources by local communities to satisfy their daily needs $[2,3]$ particularly in sub-Saharan countries where communities' livelihoods depend mainly on natural resources. Changes in land use and land cover contribute significantly to alter the environment and ecosystem services that support human needs [4, 5]. To natural resources dependent-societies, land use and land cover change constitute a major challenge to sustainable livelihoods aspirations. To implement remedial strategies to cope with the issue, a good understanding of the direction of change and their extent is needed.

Land use is defined as human' intervention on land [6] and involves both the manner in which the land is manipulated and the intent that motivated that manipulation [7]. Land cover refers to the biophysical attributes of the earth's surface [8]. The causes of land use land cover change can be summarized in two major categories namely the proximate or direct causes and the underlying causes [9, 10]. The underlying causes are factors that trigger the proximate causes and refer to economic, demographic, institutional political or technological factors that mostly occur at regional or global levels [11]. The proximate causes refer to 
immediate actions that affect directly the land cover $[12,14]$. The proximate causes of land use and land cover changes are manifold but the most cited in Africa are wood extraction, agricultural expansion, and infrastructure extension [9, 15-18].

After forest clearing for agriculture, wood extraction mostly for household energy consumption is the major driving force of vegetation dynamics in sub-Saharan countries $[19,20]$ where woodfuel either used directly as firewood or converted into charcoal is the primary source of domestic energy [21]. Indeed, despite the capacity of tropical forest species to regenerate after cutting for charcoal that allows forest recovery [22, 24], the pressure exerted by charcoal production sometimes results in devastating ecological and environmental effects [25] particularly deforestation and forest degradation [26, 27]. The environmental effects of deforestation often prompt countries with high dependence on fuel wood to develop strategies for coping with the problem. In Senegal a major charcoal producing country, the concern for unsustainable production of charcoal and the need to halt the process of deforestation and forest degradation induced by charcoal production led to the evolution of forest management in which formal forest regulation backed by management plans was introduced in local communities [28].

In different studies conducted in Senegal, the evolution of decentralization of the forest management process [29], the effect of the institutional pluralism on the decentralization and the management of forest resources [30], the function of the forest management plan in the new Senegalese Forest code [31], the evolution of forest management in Senegal [32] were analysed. With the exception of a study by [33] that examined the effects of charcoal production on woodland regeneration, all these studies focused on the political and institutional framework of forest management. However, the ultimate impact of these new forest management arrangements on deforestation is yet to be determined. Therefore, this study was carried out to find out how these political and institutional changes embodied in the new approach to forest management impact on land use and land cover change in the country. Using the Missirah Forest in south-eastern Senegal, as a case study, the research sought to quantify the land use and land cover changes that have happened over a twenty four- year period, from 1990 to 2014 using remote sensing.

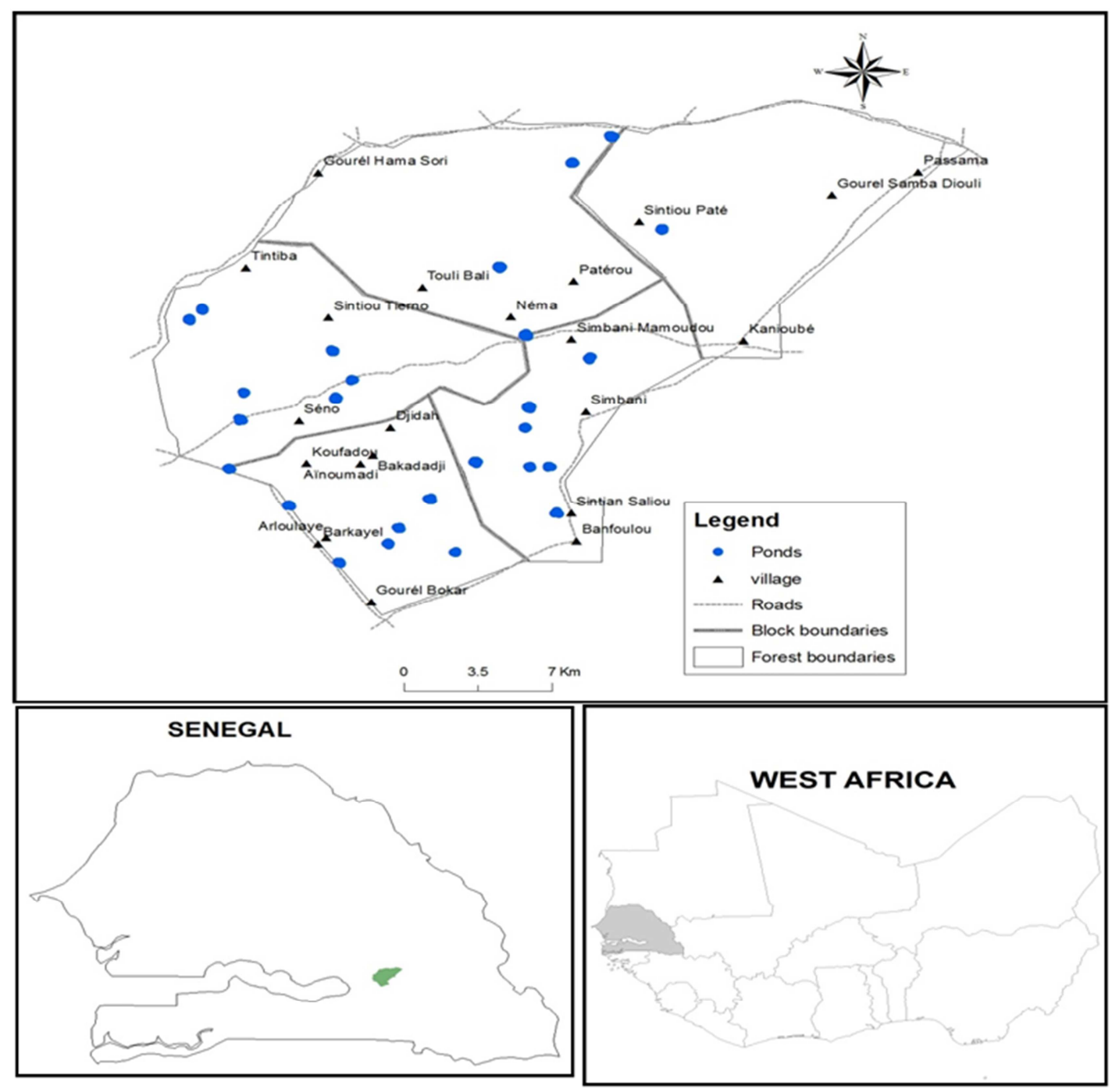

Figure 1. Location of Missirah Forest. 


\section{Materials and Methods}

\subsection{Study Area}

This study was conducted in Missirah Forest which is located in the Sudanian zone in south-eastern Senegal. The total area of the forest is 63123.54 ha and the vegetation is dominated by species such as Combretum glutinosum, Cordyla pinnata, Pterocarpus erinaceus, Bombax costatum, Lannea acida, and Acacia macrostachya. The study area is characterized by distinct dry and wet seasons. The mean annual rainall from 1960 to 2014 is estimated at $754 \mathrm{~mm}$. Temperatures range from 42 to $16^{\circ} \mathrm{C}$ with a mean of $29^{\circ} \mathrm{C}$. The management of Missirah Forest dates back to 2004 with the support of a World Bank project. The management is based on a plan that specifies when, where and the volume of wood to be cut, methods to be used and reforestation activities for replacing the losses [28]. The forest is divided into five (5) blocks split up each into eight (8) plots of exploitation. This corresponds to eight years rotation period. Gallery forest and croplands were classified as protected areas in the management plan and consequently proscribed to charcoal production activities. Resident communities were allowed to maintain their croplands but forbidden to extend or open new farms.

\subsection{Estimation of Land Use and Land Cover Change}

\subsubsection{Remote Sensing and Field Data}

The dynamics of the land use and land cover were studied using time series of Landsat images obtained from Landsat TM (Thematic Mapper), of 11/29/1990, ETM+ (Enhanced Thematic Mapper) of $01 / 01 / 2003$ and Landsat OLI (Operational Land Imager) of 02/24/2014 corresponding to scene $203 / 51$. The images were acquired approximatively for the same period, at the beginning of the dry season to ensure that the phenological stages of plant cover were not too different between dates. Moreover the beginning of the dry season is a suitable period to distinguish the various SudanoSahelian land-cover types because the contrast between the croplands and the natural environment is more marked [34]. Also, images captured in the dry season have the advantage of low cloud cover. Images used were downloaded from the United States Geological Survey (USGS) Landsat Earth Resources Observation Systems (EROS) Data Center. A ground survey was also carried out in the beginning of the dry season in conformity to the period of image acquisition. A set of 111 GPS points were collected in the different vegetation types and land use types. More GPS points were collected in classes that were more difficult to separate. The vegetation types were identified based on the classification of Yangambi [35]. Species in the vegetation types visited were also recorded.

\subsubsection{Image Processing}

As a first step we did a visual analysis that corresponds to the traditional method of photo-interpretation of the satellite images. This method consists of identifying the different homogenous units [36]. The interpretation was often made easy by our knowledge of the vegetation and field surveys.

The images used were already all geo-rectified to UTM WGS 84 Zone 28 North coordinates with radiometric corrections. To avoid geographical deviation between images due to differences in sensor when superimposing them for change detection analysis, the images of 1990 and 2003 were georectified to the image of 2014 already corrected using ground survey. The images were georectified using an image to image adjustment with an error estimated to less than the value of one pixel.

After adjusting the images, coloured compositions were created by combining channels 5 for the infrared [0.75-0.90 $\mu \mathrm{m}], 4$ for the red [0.63 to $0.69 \mu \mathrm{m}$ ] and 3 for the green [0.52 to $0.60 \mu \mathrm{m}$ ] that display respectively the red, green, and blue colours for images 1990 and 2003. Regarding 2014 image, that was done associating the channels 6 for the infrared

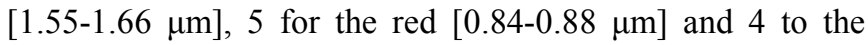
green $[0.63-0.68 \mu \mathrm{m}]$. Then, the study area was extracted from the scene to determine the land cover land use types by classifying images.

A supervised classification was performed using the maximum likelihood algorithm. The choice of the classification type was motivated by heterogeneity of the study area that may favour high probability of confusion between some classes. The classification was parameterized by digitizing training areas. Prior to the determination of training areas, the number of classes was defined. The determination of the number of classes was based on the unsupervised classification performed up stream and the information collected in the field. To homogenize the classification, the images were subjected to $3 \times 3$ pixels filter. To check the accuracy of the classifications, a confusion matrice was created for each year to determine the overall accuracy and the kappa coefficient. The accuracy assessment showed good classification with kappa coefficient of more than $80 \%$ for 2014 image taken as reference. The different classes derived from the images were also compared with existing documents (thematic and synthetic maps of the study area). All the processing was performed using Envi 4.7.

The classified images were vectorized and processed using Arc Gis to produce land cover maps for the different periods. The post-classification comparison which is the most appropriate way to compare multi-source data [34] was used for change detection analysis. The analysis of the land use and land cover change was done taking into consideration the modifications and conversion processes observed between the different periods. Modifications refer to changes that affect the character without changing the category while conversions concern the replacement of one category by another [37]. A second temporal analysis of transition among vegetation types was carried out to determine the proportion of transition to less and more wooded vegetation. 


\section{Results}

\subsection{State of Land Use Land Cover in 1990, 2003 and 2014}

The land use and land cover mapping identified six classes namely gallery forest, tree savanna, shrub savanna, degraded shrub savanna, croplands, and settlements. Land cover statistics (Table 2) showed the respective dominance of shrub savanna, tree savanna, croplands, gallery forests, and settlements in 1990 and 2003. In the 2014 image a new land cover type designated as degraded shrub savanna was identified as a distinctive land cover type. It thus became the fourth land cover type with $10.82 \%$ of the total area next to shrub savanna $(42.35 \%)$, tree savanna $(25.25 \%)$ and croplands $(18.15 \%)$. Degraded shrub savanna is dominated by grasses with many dead tree trunks and few shrubs. In some spots it is even devoid of shrubs and thus differs from shrub savanna in terms of woody cover.

Table 1. Land use/land covers statistics of Missirah Forest in 1990, 2003, and 2014.

\begin{tabular}{|c|c|c|c|c|c|c|}
\hline \multirow{2}{*}{ Land use land cover types } & \multicolumn{2}{|l|}{1990} & \multicolumn{2}{|l|}{2003} & \multicolumn{2}{|l|}{2014} \\
\hline & Area (ha) & Percentage & Area (ha) & Percentage & Area (ha) & Percentage \\
\hline Gallery forest & 2799.02 & 4.43 & 2428.43 & 3.85 & 1655.87 & 2.62 \\
\hline Tree savanna & 26234.68 & 41.56 & 19948.09 & 31.60 & 15938.27 & 25.25 \\
\hline Shrub savanna & 29626.66 & 46.94 & 30547.82 & 48.40 & 26730.72 & 42.35 \\
\hline Croplands & 4231.00 & 6.70 & 9939.36 & 15.75 & 11459.45 & 18.15 \\
\hline Settlements & 230.18 & 0.36 & 257.83 & 0.41 & 508.89 & 0.81 \\
\hline Degraded shrub savanna & - & - & - & - & 6828.34 & 10.82 \\
\hline
\end{tabular}

For the three different assessment occasions the forest was dominated by shrub savanna and tree savanna that together represented $88.50 \%$ of the area in $1990,80 \%$ in 2003 , and $67.60 \%$ in 2014 . Tree savanna and gallery forest gradually cover decreased between 1990 and 2014. The area covered by tree savanna decreased progressively from $41.56 \%$ in 1990 to $25.25 \%$ in 2014 . Gallery forest accounted for $4.43 \%$ of the area in 1990 but only $2.62 \%$ in 2014 . Croplands more than doubled between 1990 and 2003 from $6.70 \%$ to $15.75 \%$ but expanded more slowly from 2003 to 2014. The settlements presented an inverse scenario. They almost doubled between $2003(0.41 \%)$ and $2014(0.81 \%)$ whereas for the first period a slight increase of $0.05 \%$ was noticed. Shrub savanna the most dominant land cover type for the three periods increased by $1.46 \%$ between 1990 and 2003 and showed a decrease of $6.05 \%$ from 2003 to 2014 due to degradation. The diachronic land cover maps obtained for the three periods are presented in Figure 2.

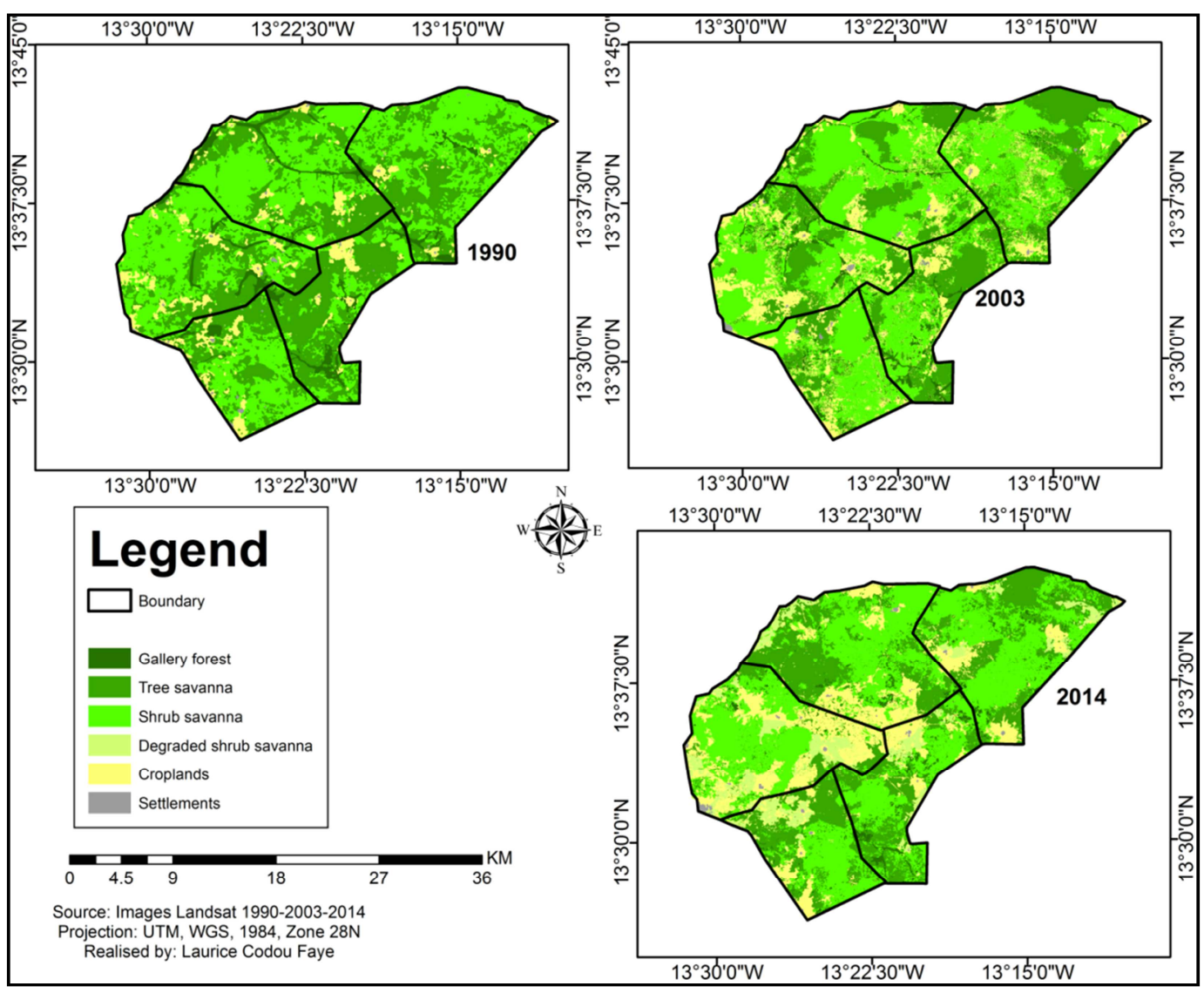

Figure 2. Missirah Forest in 1990, 2003, and 2014. 


\subsection{Change Detection Analysis}

\subsubsection{Land Use Land Cover Dynamics}

Annual rate of land cover change was unidirectional for all land cover types with the exception of shrub savanna (Figure 3 ). The rate of change was positive in all periods for croplands and settlements contrary to tree savanna and gallery forest. The overall annual rate of change (1990-2014) was highest for croplands with an increase of $11.45 \%$ and lowest for settlements $(0.44 \%)$. Tree savanna recorded the greatest loss between 1990 and 2014 (-16.31\%).

The matrices of land cover change presented in Table 2 reveal that from 1990 to 2003, 43.61\% of the area remained stable, $16.20 \%$ got converted and $40.19 \%$ was modified while from 2003 to 2014 conversions reached $23.30 \%$ of the total area with only $38.60 \%$ remaining stable. The unchanged area of each class is presented in diagonal elements (bold figures) in Table 2. For the first period (1990-2003), shrub savanna with $53.20 \%$ of its surface had the highest proportion of unchanged area followed by croplands $(48.60 \%)$. In the second period, settlements and shrub savanna were the most stable land cover types with $51.20 \%$ and $46.40 \%$ of their area respectively remaining unchanged.

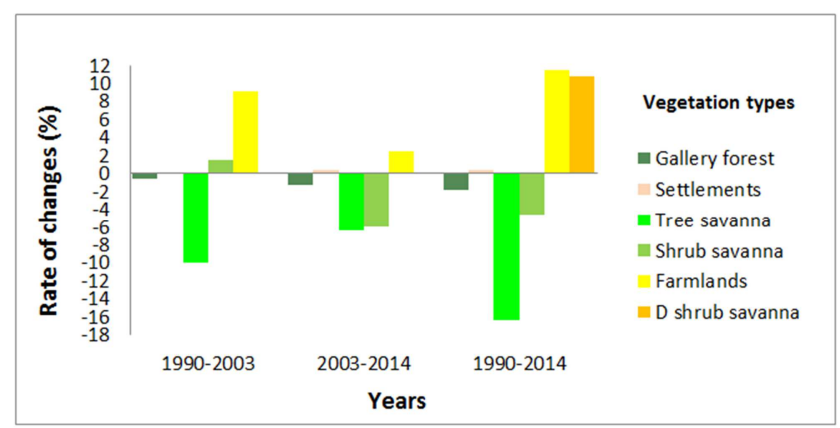

Figure 3. Annual rates of land cover change in Missirah Forest between 1990 and 2014.

Table 2. Matrices of land cover change in Missirah Forest between 1990 and 2014.

\begin{tabular}{|c|c|c|c|c|c|}
\hline & \multicolumn{5}{|c|}{ From 1990 to 2003} \\
\hline & Gallery forest & Tree savanna & Shrub savanna & Croplands & Setllements \\
\hline Gallery forest & 27.06 & 3.59 & 2.22 & 1.61 & 0.00 \\
\hline Tree savanna & 23.45 & 33.99 & 31.98 & 20.35 & 16.09 \\
\hline Shrub savanna & 37.01 & 48.03 & 53.2 & 25.77 & 25.24 \\
\hline Croplands & 12.48 & 14.19 & 12.53 & 48.6 & 44.28 \\
\hline \multirow[t]{2}{*}{ Setllements } & 0.00 & 0.2 & 0.07 & 3.66 & 13.9 \\
\hline & Gallery forest & Tree savanna & Shrub savanna & Croplands & Setllements \\
\hline Gallery forest & 9.73 & 2.53 & 2.2 & 2.42 & 0.44 \\
\hline Tree savanna & 25.56 & 32.01 & 22.95 & 19.25 & 0.18 \\
\hline Shrub savanna & 41 & 42.2 & 46.4 & 31.17 & 17.64 \\
\hline Degraded shrubsavanna & 5.47 & 10.14 & 11.99 & 10.05 & 3.57 \\
\hline Croplands & 17.38 & 12.59 & 15.78 & 35.66 & 23.74 \\
\hline \multirow[t]{2}{*}{ Setllements } & 0.85 & 0.54 & 0.67 & 1.43 & 51.2 \\
\hline & Gallery forest & Tree savanna & Shrub savanna & Croplands & Setllements \\
\hline Gallery forest & 10.15 & 2.28 & 2.33 & 1.88 & 2.21 \\
\hline Tree savanna & 23.40 & 28.14 & 25.33 & 8.82 & 9.71 \\
\hline Shrub savanna & 44.00 & 45.01 & 42.88 & 20.63 & 27.89 \\
\hline Degraded shrubsavanna & 5.16 & 7.87 & 13.67 & 12.94 & 9.79 \\
\hline Croplands & 16.63 & 16.25 & 14.83 & 52.94 & 42.16 \\
\hline Setllements & 0.65 & 0.46 & 9.73 & 2.78 & 29.96 \\
\hline
\end{tabular}

The dynamics concerned mostly changes from tree savanna and gallery forest to shrub savanna in both periods 1990-2003 and 2003-2014. In the first period, $48.03 \%$ of tree savanna and $37.01 \%$ of gallery forest were changed into shrub savanna. In the second period, tree savanna was still most affected with $42.2 \%$ of its area but the proportion of gallery forest that changed into shrub savanna (41\%) was higher than the previous change. From gallery forest to tree savanna, the change was also quite high affecting more than $20 \%$ of its area. With regard to shrub savanna, the change was mostly toward tree savanna with $31.98 \%$ and $22.95 \%$ of its area respectively in the first and the second period. The transition of tree and shrub savanna into gallery forest was not important in both periods. The transition into degraded shrub savanna newly appeared in 2014 images, and was more important for shrub savanna followed by tree savanna and degraded gallery forest respectively with $11.99 \%, 10.14 \%$, and $5.47 \%$ of their area.

With regard to conversions from natural vegetation to cropland between 1990 and 2003, it occurred as follows: tree savannah (14.19\%), shrub savannah $(12.53 \%)$, and gallery forest (12.48\%); and between 2003 and 2014, conversions appeared in the following order: gallery forest (17.38\%) shrub savannah (15.78\%) and tree savannah (12.59\%). Conversions from cropland to natural vegetation in the first period took place in the following order shrub savannah 
$(25.77 \%)$, tree savannah $(20.35 \%)$, and gallery forest $(1.61 \%)$; in the second period, the same order was observed except that the conversion into degraded shrub savanna $(10.05 \%)$ was higher than conversion into gallery forest $(2.42 \%)$.

Conversions from natural vegetation to croplands were more important in terms of magnitude than those from cropland to natural vegetation. Area of natural vegetation converted into cropland in the first period and second period were estimated at $12.33 \%$ and $14.28 \%$ respectively. However, from croplands to natural vegetation conversions were estimated at $3.20 \%$ in the first period and $8.32 \%$ in the second period. Generally from 1990 to 2014, the conversions into croplands reached $14.45 \%$ of the total area whilst from croplands to natural vegetation, they represented only $3 \%$. Figure 4 presented the spatial distribution of these transitions. The transition from natural vegetation to cropland is considered as "new croplands", resulting from forest clearing, from cropland to natural vegetation "abandoned croplands", that indicates also a recovery of the vegetation cover and the unchanged area of cropland as "permanent croplands".

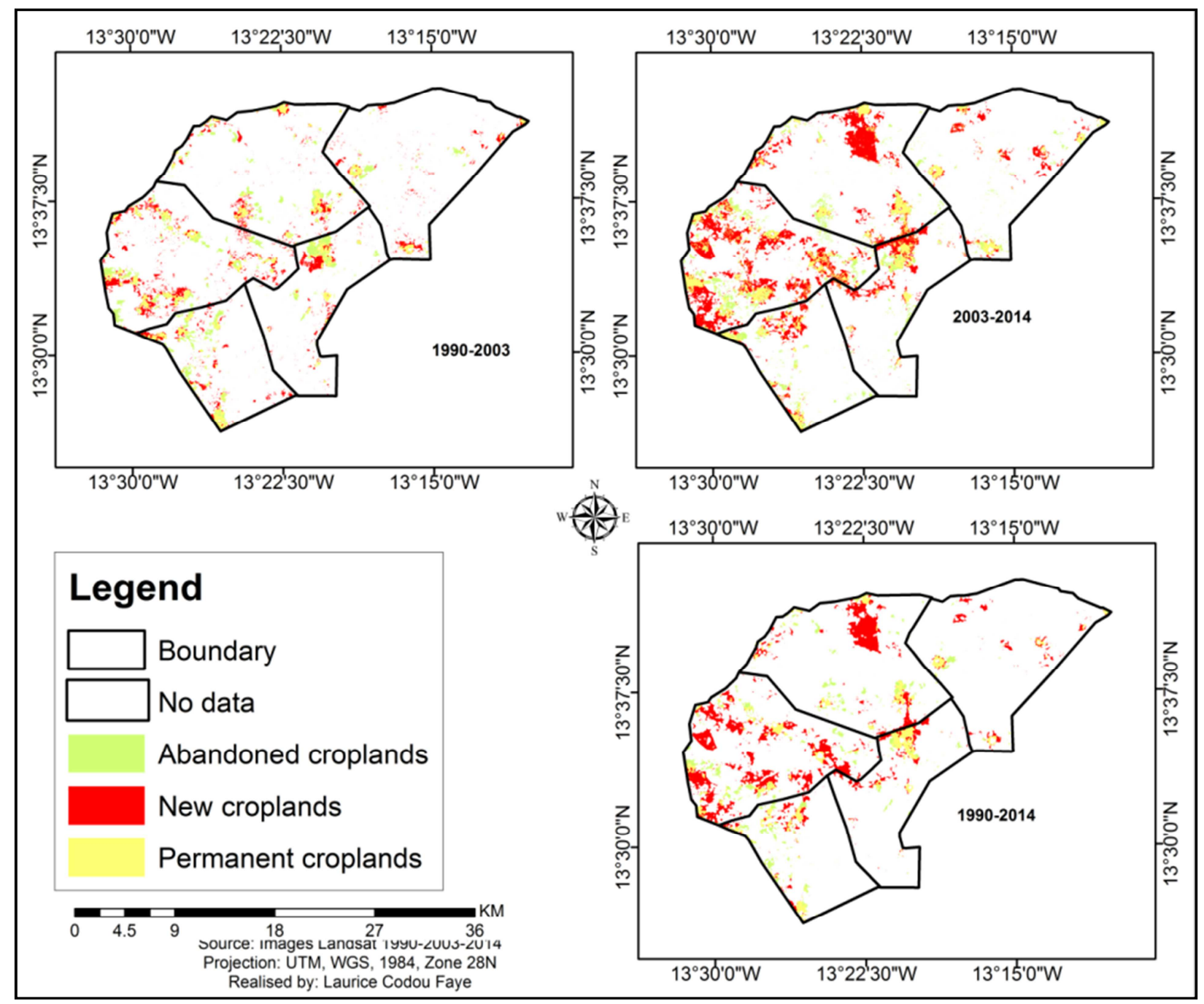

Figure 4. Transition between natural vegetation and croplands in Missirah Forest for the three periods (1990-2003; 2003-2014; 1990-2014).

\subsubsection{Transition Among Vegetation Types}

In Table 3 are found the statistics of the transition among natural vegetation cover types. The transition to less wooded vegetation was of a higher magnitude than transition to more wooded vegetation in both periods. However, the difference was more marked in the second period when a management plan was implemented. While in the first period the transition to less wooded vegetation was $5.08 \%$ more than the transition to more wooded vegetation, in the second period, it almost doubled. The transition among vegetation types was mainly characterized by transition between tree savanna and shrub savanna. The transition from shrub savanna to tree savanna balanced each other in the two periods respectively with $11.11 \%$ in the first period and $11.88 \%$ during the second period. But regarding transition from tree savanna to shrub savanna the highest value was recorded in the first period with $19.96 \%$ of the forest whereas in the second it was estimated at $13.33 \%$. The transition into degraded shrub savanna in the second period was also important affecting $10 \%$ of the total forest area. 
Table 3. Temporal analysis of transition among vegetation types in Missirah Forest between 1990 and 2014.

\begin{tabular}{|c|c|c|c|}
\hline (a) $1990-2003$ & & & \\
\hline Transition to less wooded vegetation (\%) & & Transition tomore wooded vegetation (\%) & \\
\hline Gallery forest to tree savanna & 1.04 & Tree savanna to gallery forest & 1.49 \\
\hline Gallery forest to shrub savanna & 1.64 & Shrub savanna to gallery forest & 1.04 \\
\hline Tree savanna to shrub savanna & 19.96 & Shrub savanna to tree savanna & 11.09 \\
\hline Total & 22.62 & Total & 17.54 \\
\hline \multicolumn{4}{|l|}{ (b) 2003-2014 } \\
\hline Transition to less wooded vegetation (\%) & & Transition to more wooded vegetation (\%) & \\
\hline Gallery forest to tree savanna & 0.98 & Tree savanna to gallery forest & 0.79 \\
\hline Gallery forest to shrub savanna & 1.57 & Shrub savanna to gallery forest & 1.06 \\
\hline Gallery forest to deg. shrub savanna & 0.21 & Shrub savanna to tree savanna & 11.11 \\
\hline Tree savanna to shrub savanna & 13.33 & & \\
\hline Tree savanna to deg. shrub savanna & 3.2 & & \\
\hline Shrub savanna to deg. shrub savanna & 5.8 & & \\
\hline Total & 25.09 & Total & 12.96 \\
\hline \multicolumn{4}{|l|}{ (c) $1990-2014$} \\
\hline Transition to less wooded vegetation (\%) & & Transition to more wooded vegetation(\%) & \\
\hline Gallery forest to tree savanna & 1.03 & Tree savanna to gallery forest & 0.94 \\
\hline Gallery forest to shrub savanna & 1.95 & Shrub savanna to gallery forest & 1.09 \\
\hline Gallery forest to deg. shrub savanna & 0.22 & Shrub savanna to tree savanna & 11.88 \\
\hline Tree savanna to shrub savanna & 18.7 & & \\
\hline Tree savanna to deg. shrub savanna & 3.27 & & \\
\hline Shrub savanna to deg. shrub savanna & 6.41 & & \\
\hline Total & 31.58 & Total & 13.91 \\
\hline
\end{tabular}

\section{Discussion}

The dynamics of the vegetation was characterized by a process of degradation and deforestation that manifested respectively as transition from wooded to less wooded vegetation and the reduction of forest cover following forest clearing. Conversions affected tree savanna more than the other vegetation cover types (14.19\%) in the first period and gallery forest in the second period (17.38\%). In both periods shrub savanna came in second position but with a higher proportion in the second period $(15.78 \%)$. The importance of the proportion of shrub savanna converted in the second period may be due to areas harvested for charcoal that were subsequently converted to croplands. Agricultural expansion taking advantage of logging or tree harvesting for charcoal is a common occurrence in developing countries [38]. One important finding of this study was the appearance of a new land cover type that we called degraded shrub savanna in 2014. This land cover type is mainly the result of tree and shrub density decline in tree savanna and the shrub savanna vegetation types. It is an open-vegetation consisting mainly of grass cover with a few shrubby species. A similar observation was made in eastern and southern Africa where charcoal production led to the transition of woodland to bush and bush to scrub [39]. It was observed that a reduction of about $20.9 \%$ of the forest cover and an expansion of cropland areas occurred within the period 1990 to 2014 . This change is higher than the decrease in forest cover (4.1\%) observed at national level by [40] between 1965 and 2000, a period of 35 years. The difference may be explained by two factors. First, they took into account the whole vegetation cover at national level including protected areas where there is no human footprint because they are protected (protected forests reserves and sanctuaries) and are consequently devoid of human pressure. Second, pressure from exponential growth of human population and livestock was probably not so high at that time. Our estimation also exceeded their findings on deforestation for the region where the study was conducted. Here the reduction of the woody cover following cutting for charcoal production was estimated between 15 and $20 \%$ in 1965 against 5 to $20 \%$ in 2004 . The same trend was observed in other parts of the country specifically in the peanut basin located in west-central Senegal [41]. and in the Ferlo, northern part of Senegal where from 1976 to 1995 the woody cover decreased from $10-15 \%$ to $1-5 \%$ [42].

The croplands were characterized by a continuous expansion between the two periods to the detriment of natural vegetation cover. This result matches with the findings of many authors [2, 34, 43-44] who using remote sensing, documented an increase of croplands following vegetation cover clearance. Similar results have also been reported elsewhere in the central part of Senegal in Patako Forest [45] and in the peanut basin [46]. However, our findings contradict those of [47] in the river valley (northern Senegal) and [48] in south-western part of Senegal who documented a reduction in croplands. This difference could be explained by the fact that both studies concern agriculture in flooded areas where a combination of rainfall decrease and 
increase in temperature has exacerbated soil salinity leading to the abandonment of many ricefields by farmers. The increase in cropland observed in the study was more important between 1990 and 2003 (150\%) than from 2003 to $2014(30 \%)$. This finding is consistent with the scenario observed at the national level where the annual expansion rate of cropland was estimated at $27.72 \%$ between 1965 and 1985 and $20.53 \%$ from 1985 to 2000 [40]. The high increase of cropland between 1990 and 2003 may be explained by migration of farmers from the west towards the south-eastern part of Senegal under the project "terres neuves" that relocated people and created new villages to increase the production of groundnut [49-50]. Indeed, migration is an important factor driving land use change as argued by [37, 51]. Furthermore, this period coincided with a growing interest in cotton production with the establishment of the "Société de Développement et des Fibres Textiles" (SODEFITEX). It boosted the production of cotton by providing technical support, seeds, fertilizer, and credit for equipment purchase. Then, in this favourable context of technology and marketing, the area cultivated for cotton experienced a significant increase. The experience in Burkina Faso is the same $[11,52]$. In the second period (2003-2014), in spite of the population growth and settlement expansion recorded in the area, the expansion rate of croplands was lower. However, contrary to the findings of [53] in the Volta Basin of Ghana who concluded that the slowing in cropland expansion was due to agricultural intensification, in Missirah Forest the crisis in cash crop production (cotton and ground nut), and the introduction of charcoal production in the area by a World Bank project which is more economically rewarding than agriculture, could be the two main explanatory factors.

\section{Conclusion}

Forest management was introduced to improve forest quality and ensure security of local livelihoods. Our results show that the extent of changes in land use and land cover types does not point to sustainable use of resources. Missirah Forest has been significantly cleared for cropland expansion whilst tree harvesting for charcoal production has led to more open vegetation. The change has been more important in the second period signifying a trend towards more degradation. This means the implementation of the forest management plan ought to be strengthened.

Results from the present investigation provides information on historical and current land use land cover changes that may be useful in improving existing forest management especially spatial processes. Suggestions derived from this study can be summarized into three points. First, there is a necessity to discourage croplands expansion by making effective the intensification of agriculture to cope with the increase in demand for food and/or sale and land degradation. Second, the promotion of other livelihoods other than farming and charcoal production will reduce the pressure exerted on forest which is the main source of incomes. Third, law-enforcement should be strengthened to avoid clearing of protected areas.

\section{Acknowledgments}

This study was supported by the West African Science Service Center on Climate Change and Adapted Land use (WASCAL) programme on Climate Change and Land Use which is funded by the German Federal Ministry for Education and Research (BMBF).

\section{References}

[1] Yeshaneh, E., Wagner, W., Exner-Kittridge, M., Legesse, D., \& Blöschl, G. (2013). Identifying Land Use/Cover Dynamics in the Koga Catchment, Ethiopia, from Multi-Scale Data, and Implications for Environmental Change. International Journal of Geo-Information, 2, 302-323.

[2] Nacoulma, B. M. I., Schumann, K., Traoré, S., Marcus, B. R., Karen, H., Rudiger, W., \& Thiombiano, A. (2011). Impacts of land-use on West Africa savanna vegetation: a comparison between protected and communal area in Burkina Faso. Biodiversity and Conservation. doi: Springer [DOI 10.1007/s 10531-011-0114-0].

[3] Kadeba, A., Nacoulma, B. M. I., Ouedraogo, A., Bachmann, Y., Thiombiano, A., Schmidt, M., \& Boussim, J. I. (2015). Land cover change and plants diversity in the Sahel: A case study from northern Burkina Faso. Annals of Forest Research, 58(1), 109-123.

[4] Le, Q. B., Parkb, S. J., Vlek, P. L. G., \& Cremersc, A. B. (2008). Land-Use Dynamic Simulator (LUDAS): A multiagent system model for simulating spatio-temporal dynamics of coupled human-landscape system. I. Structure and theoretical specification. Ecological I nformatics 3, 135-153.

[5] Mayaux, P., Pekel, J.-F., Desclée, B., Donnay, F., Lupi, A., Achard, F.,... Nasi, R. (2013). State and evolution of the African rainforests between 1990 and 2010. Philosophical Transactions of the Royal Society B: Biological Sciences, 368(1625), 20120300.

[6] Meshesha, D. T., Tsunekawa, A., \& Tsubo, M. (2010). Continuing land degradation: cause-effects in Ethiopia's central rift valley. Land Degradation \& Development. doi: 10.1002/Idr.1061.

[7] Turner Ii, B., Skole, D., Sanderson, S., Fischer, G., Fresco, L., \& Leemans, R. (1995). Land-use and land-cover change. Science/Research plan.

[8] Lambin, E. F., Turner, B. L., Geist, H. J., Agbola, S. B., Angelsen, A., Bruce, J. W.,... Folke, C. (2001). The causes of land-use and land-cover change: moving beyond the myths. Global Environmental Change, 11(4), 261-269.

[9] Geist, H. J., \& Lambin, E. F. (2002). Proximate Causes and Underlying Driving Forces of Tropical Deforestation. BioScience, 52(2), 143-150.

[10] Ikpa, T. F., Debra, B. A., \& Jande, J. A. (2009). Biodiversity conservation: why local inhabitants destroy habit in protected areas. Science World Journal, 4, 22-27. 
[11] Ouedraogo, I., Tigabu, M., Savadogo, P., Compaore, H., Ode, P. C., \& Ouadba, J. M. (2010). land cover change and its relation with population dynamics in burkina faso, west africa. (2010). Land Degradation and Development.. doi: 10.1002/ldr.981 www.interscience.wiley.com.

[12] Braimoh, A. K. (2004a). Seasonal migration and land-use change in Ghana. Land Degradation \& Development 15, 37-47.

[13] Fox, J., \& Vogler, J. B. (2005). Land-use and land-cover change in montane mainland southeast Asia. Environmental Management, 36(3), 394-403.

[14] Hosonuma, N., Herold, M., De Sy, V., De Fries, R. S., Brockhaus, M., Verchot, L.,... Romijn, E. (2012). An assessment of deforestation and forest degradation drivers in developing countries. Environmental Research Letters, 7(4), 044009 .

[15] Carr, D. L. (2004). Proximate population factors and deforestation in tropical agricultural frontiers. Population and environment, 25(6), 585-612.

[16] Hansen, C. P., Lund, J. F., \& Reue, T. (2009). Neither fast, nor easy: the prospect of Reducing Emissions from Deforestation and Degradation (REDD) in Ghana. International Forestry Review, 4, 439-455.

[17] Norris, K., Asase, A., Collen, B., Gockowksi, J., Mason, J., Phalan, B., \& Wade, A. (2010). Biodiversity in a forestagriculture mosaic-The changing face of West African rainforests. Biological Conservation, 143(10), 2341-2350.

[18] Damnyag, L., Saastamoinen, O., Blay, D., Dwomohb, F. K., Anglaaere, L. C. N., \& Pappinen, A. (2013). Sustaining protected areas: Identifying and controlling deforestation and forest degradation drivers in the Ankasa Conservation Area, Ghana. Biological Conservation 165, 86-94.

[19] Arnold, M., Köhlin, G., \& Person, R. (2005). Woodfuels, livelihoods and policy interventions: changing perspectives. World Development, 34 ( $\left.n^{\circ} 3\right)$, 496-511.

[20] Kouami, K., Yaovi, N., \& Honan, A. (2009). Impact of charcoal production on woody plant species in West Africa: A case study in Togo. Scientific Research and Essay 4(9), 881-893.

[21] Karekezi, S. (2002). Poverty and energy in Africa - a brief review. Energy Policy, 30, 915-919.

[22] Ribot, J. C. (1993). Forestry policy and charcoal production in Senegal. Energy Policy, 21, 543-585.

[23] Nygård, R., Sawadogo, L., \& Elfving, B. (2004). Wood-fuel yields in short-rotation coppice growth in the north Sudan savanna in Burkina Faso. For Ecol Manage, 189, 77-85.

[24] Aguilar, R., Ghilardi, A., Vega, E., Skutsch, M., \& Oyama, K. (2012). Sprouting productivity and allometric relationships of two oak species managed for traditional charcoal making in central Mexico.. Biomass Energy, 36, 193-207.

[25] Chidumayo, E. N., \& Gumbo, D. J. (2013). The environmental impacts of charcoal production in tropical ecosystems of the world: A synthesis. Energy for Sustainable Development, 17, 86-94.

[26] Luoga, E. J., Witkowski, E. T. F., \& Balkwill, K. (2002). Harvested and standing wood stocks in protected and communal miombo woodlands of eastern Tanzania. For Ecol Manage, 164, 15-30.
[27] Mwampamba, T. H. (2007). Has the woodfuel crisis returned? Urban charcoal consumption in Tanzania and its implications to present and future forest availability. Energy Policy, 35(8), 4221-4234. doi: http://dx.doi.org/10.1016/j.enpol.2007.02.010.

[28] Agrawal, A., \& Ribot, J. (1999). Accountability in decentralization: a framework with South Asian and West African cases. The Journal of Developing Areas, 473-502.

[29] Poteete, A. R., \& Ribot, J. C. (2011). Repertoires of Domination: Decentralization as Process in Botswana and Senegal. World Development, 39(3), 439-449.

[30] Faye, P. (2006). Décentralisation, pluralisme institutionnel et démocratie locale : Étude de cas de la gestion du massif forestier Missirah/Kothiary (région de Tambacounda, Sénégal). Conseil pour le développement de la recherche en sciences sociales en Afrique World Resources Institute Centre de Coopération Internationale en Recherche agronomique pour le Développement.

[31] Ribot, J. C. (2009). Analysis of Senegal's draft forestry code: With special attention to its support for decentralization laws. USAID (pp. 68). Dakar, Senegal.

[32] Ribot, J. C. (2001). Historique de la gestion forestière en Afrique de l'Ouest: Ou: comment la" science" exclut les paysans: International Institute for Environment and Development, Programme zones arides.

[33] Wurster, K. (2010). Management matter? Effects of charcoal productions management on woodland regeneration in Senegal. (Ph. D dissertation), University of Marylan, USA.

[34] Ruelland, D., Levavasseur, F., \& Tribotte, A. (2010). Patterns and dynamics of land-cover changes since the 1960s over three experimental areas in Mali. International Journal of Applied Earth Observation and Geoinformation, 12, 11-17.

[35] Aubreville, A. (1957). Accord à Yamgambi sur la nomenclature des types africains de végétation. Bois et Forêts des Tropiques, 51, 23-27.

[36] Hammi, S., Simonneaux, V., Alifriqui, M., Auclair, L., \& Montes, N. (2007). Evolution des recouvrements forestiers et de l'occupation des sols entre 1964 et 2002 dans la haute vallee des Ait Bouguemez (Haut Atlas central, Maroc). Secheresse 18, 271-277.

[37] Lambin, E. F., Geist, H. J., \& Lepers, E. (2003). Dynamics of land use and land cover change in tropical regions. Annual Review of Environment and resources, 28: 205-241. doi: 10.1146/annurev.energy.28.050302.105459.

[38] Chidumayo, E. N., Masaileti, I., Ntalasha, H., \& Kalumiana, O. S. (2001). Charcoal potential in southern Africa (CHAPOSA) - report for Zambia. Stockholm: Stockholm Environment Institute.

[39] Arnold, M., \& Persson, R. (2003). Reassessing the fuelwood situation in developing countries. 2003; 5:. International Forestry Review, 5, 379-383.

[40] Tappan, G. G., Sall, M., Wood, E. C., \& Cushing, M. (2004). Ecoregions and land cover trends in Senegal. Journal of Arid Environments 59, 427-462.

[41] Wood, E., Tappan, G., \& Jacobs, D. (1995). Monitoring Senegal's natural resources using airborne videography. Proceedings. Paper presented at the 15th Biennial Workshop on Color Photography and Videography in Resource Assessment. Terre haute, Indiana. 315-325. 
[42] CSE. (1998). La vegetation ligneuse du Sene'gal: distribution, dynamique et fonction (pp. 52). Dakar, Senegal.

[43] Ouédraogo, I. (2006). Land use dynamics in Bieha district, Sissili province; southern Burkina Faso, West Africa. Umoja: Bulletin of the African and American Studies, 1 (2), 18-34.

[44] Pare, S., Soderberg, U., Sandewall, M., \& Ouadba, J. M. (2008). Land use analysis from spatial and field data capture in southern Burkina Faso, West Africa. Agriculture, Ecosystems \& Environment, 127, 277-285.

[45] Guiro, I., Mbow, C., Baret, F., \& Diaw, A. T. (2012). Dynamique de l'occupation du sol de la forêt classée de Patako et de sa périphérie de 1972 à 2002. Revue de Géographie du Laboratoire Leïdi.

[46] Tappan, G., Hadj, A., Wood, E., \& Lietzow, R. (2000). Use of argon, corona, and landsat imagery to assess 30 years of land resource changes in west-central Senegal. Photogram metric Engineering and Remote Sensing, 66(6), 727-735.

[47] Sarr, M. A. (2002). Cartographie des changements de l'occupation du sol entre 1990 et 2002 dans le nord du Sénégal (Ferlo) à partir des images Landsat URL: http://cybergeo.revues.org/index 22707. html. Cybergeo: European Journal of Geography, Environnement Nature Paysage.
[48] Sambou, H., Sambou, B., Diaw, A. T., Mbow, C., \& Traore, V. B. (2014). Remote sensing mapping of the rice field and vegetal cover and the impacts of soil factors on herbaceous in the sub-watershed of Boutolate (lower Casamance, Senegal. American Journal of Environmental Protection, 3(2), 73-82.

[49] Fall, A. S. (1992). Une réponse à la crise de l'agriculture. La migration des Sereer du Siin (Sénégal) Sociétés-EspacesTemps, 1(1), 138-149.

[50] Mbow, C., Mertz, O., Diouf, A., Rasmussen, K., \&Reenberg, A. (2008). The history of environmental change and adaptation in eastern Saloum-Senegal-Driving forces and perceptions. Global and Planetary Change, 64, 210-221.

[51] Ouedraogo, I., Savadogo, P., Tigabu, M., Cole, R., Oden, P. C., \& Ouadba, J. M. (2009). Is rural migration a threat to environmental sustainability in Southern Burkina Faso? Land Degradation \& Development, 20, 217-230.

[52] Gray, L. C. (2005). What kind of intensification? Agricultural practice, soil fertility and socioeconomic differentiation in rural Burkina Faso. Geographical Journal 171, 70-82.

[53] Braimoh, A. K., \& Vlek, L. G. (2004b). Land-Cover Change Analyses in the Volta Basin of Ghana. Earth Interactions, 8, 17. 